\title{
EDITORIAL
}

\section{Historical archive made free for all}

\author{
The archive of the International Journal of Systematic and Evolutionary Microbiology (IJSEM) has \\ been made available free online, which should be a boon for scientists, historians and the public.
}

The Society for General Microbiology (SGM) publishes the International Journal of Systematic and Evolutionary Microbiology (IJSEM) on behalf of the International Committee on Systematics of Prokaryotes of the International Union of Microbiological Societies. Now, the SGM has provided funding for the entire back archive of the IJSEM to be made freely available worldwide without a journal subscription at http://ijs.sgmjournals.org/. The current content (past 2 years) of the IJSEM will still be subject to access controls.

Systematics is the foundation for studies of all types of organisms, because it helps us to understand how one organism relates to another. The value of systematics is often underappreciated, however, for bacteria and viruses. For example, there is a huge imbalance between the $\sim 7,000$ named bacterial species and the $\sim 1,000,000$ named insect species. This is particularly important given that it is now well-known that bacteria and viruses are the most populous organisms on Earth, and furthermore, that more than $99 \%$ of bacteria have yet to be cultivated. Why should we be interested in naming and characterizing different species of bacteria? The advent of metagenomics has swelled the literature with ever-increasing estimates of numbers and types of bacteria and viruses in the biosphere. An important adjunct to genomics-based approaches is the detailed characterization of these myriad species and investigation of the relationships between them. The availability of the IJSEM archive will hopefully spur renewed interest in this area.

The IJSEM serves as the central registry for all bacterial names, is the official journal of record for almost all novel microbial taxa (excluding viruses) and is described as the cornerstone of the dynamic field of microbial systematics'. For a new bacterium to be recognized its name must be recorded in IJSEM and names of newly discovered bacteria published in other journals are not valid until they have been checked and published in IJSEM. The journal has officially validated the names of 9,263 species and genera since 1980 and has published seminal papers that have described new pathogens or bacteria or archaea that have important roles in biogeochemical processes for the first time. The journal publishes peer-reviewed papers on topics ranging from the systematics - taxonomy, nomenclature, identification, phylogeny, evolution, biodiversity, characterization and culture preservation - of prokaryotes, yeasts and yeast-like organisms to phylogenetic and evolutionary stud ies of protists (protozoa and algae) and molecular environmental papers. The initiative to 'scan in' more than 25,000 pages has provided microbiologists with a fantastic resource of fully searchable PDFs on this huge range of topics. "This large project is a significant event in the history of microbial classification," said Ron Fraser, Chief Executive of the SGM. "It will greatly benefit the scientific community to have this archive freely available worldwide." Early analyses by the SGM indicate that overall usage of the IJSEM is now markedly higher than before the free-access initiative.

If you are interested in systematics you should also consult the excellent books published by the Bergey's Manuel Trust, which some of us will remember leafing through in our student days. Bergey's Manual of Systematic Bacteriology (second edition) is available in five volumes, two of which will be published in 2009. If you prefer to use online resources, there are several excellent sites. Jean Euzeby, the IJSEM list editor, maintains an incredibly useful web resource that details all those species that have been ratified - the List of Prokaryotic names with Standing in Nomenclature can be found at http://www.bacterio.cict.fr/. Another useful site named Bacterial Nomenclature Up-to-Date has an up-to-date list of bacteria and is based on the work of Norbert Weiss, who maintained the database until his retirement in February 2003. The current database is maintained under the supervision of Manfred Kracht. Finally, a comprehensive taxonomy of the Bacteria and Archaea can be found in the Taxonomic Outline of Bacteria and Archaea (TOBA) Release 7.7, which was last updated in 2007 and can be found at http://www.taxonomicoutline.org/.

Other relevant projects include the SGM-supported NamesforLife project, which will extract taxonomically relevant information from published articles using a mark-up language. Finally, Species 2000, which is funded by the Global Biodiversity Information Facility aims to create a validated checklist of the world's species, including, of course, microorganisms.

The SGM will also put the archives of the Journal of General Virology (available now), Microbiology and the Journal of Medical Microbiology online free by the end of this year. We look forward to joining our readers in perusing classic papers from the archives of these journals. 